ГORIGINAL ARTICLE

Volume 16 Supp 12021

DOI: 10.21315/aos2021.16.s1.7

ARTICLE INFO

Submitted: 02/03/2021

Accepted: 27/05/2021

Online: $22 / 09 / 2021$

\section{Innovative Treatment Using Salmon Skin Extract as Topical Application for Traumatic Oral Ulcer Healing: Animal Models}

\author{
Syamsulina Reviantia ${ }^{*}$, Puguh Bayu Prabowo ${ }^{b}$, Lita Agustiac, \\ Isidora Karsinid
}

${ }^{a}$ Department of Oral Biology, Faculty of Dentistry, Universitas Hang
Tuah Surabaya, Kota Surabaya, fawa Timur 60111, Indonesia

${ }^{b}$ Department of Biomaterial, Faculty of Dentistry, Universitas Hang Tuah Surabaya, Kota Surabaya, fawa Timur 60111, Indonesia

'Department of Public Health, Faculty of Dentistry, Universitas Hang Tuah Surabaya, Kota Surabaya, fawa Timur 60111, Indonesia

${ }^{d}$ Department of Oral Medicine, Faculty of Dentistry, Universitas Hang

Tuah Surabaya, Kota Surabaya, fawa Timur 60111, Indonesia

${ }^{*}$ Corresponding author: syamsulinarevianti16@gmail.com

To cite this article: Revianti S, Prabowo PB, Agustia L, Karsini I (2021). Innovative treatment using salmon skin extract as topical application for traumatic oral ulcer healing: Animal models. Arch Orofac Sci, 16(Supp.1): 37-42. https://doi.org/10.21315/aos2021.16.s1.7

To link to this article: https://doi.org/10.21315/aos2021.16.s1.7

\begin{abstract}
Salmon skin extract contains high proline and hydroxyproline, and has been suggested as a potential topical agent for traumatic oral ulcer healing. The aim of this study was to evaluate the effect of salmon skin extract as traumatic oral ulcer healing. A total of 32 Wistar rats (200 g to $250 \mathrm{~g}$ ) were distributed into four groups. Group 1 served as the control group (no treatment), Group 2 was topically treated with salmon skin extract agent $4 \%$, Group 3 was topically treated with salmon skin extract agent 5\%, and Group 4 was topically treated with salmon skin extract agent $6 \%$. Traumatic ulcers at lip mucosa were performed in all rats and $0.1 \mathrm{ml}$ salmon skin extract was applied on the ulcer twice daily for seven days. The animals were euthanised on the last day of treatment. Biopsy specimens were taken from the lip mucosa in all rats for epithelial thickness evaluation and the study for number of fibroblasts by histological analysis. Significant increase in epithelial thickness and the number of fibroblasts $(p>0.05)$ was observed in salmon skin extract treatment groups as compared to the control group. Salmon skin extract $6 \%$ treatment group had the highest epithelial thickness and the number of fibroblasts amongst the study groups. Salmon skin extract promises an innovative topical application treatment for traumatic oral ulcer healing. Salmon skin extract $6 \%$ was the most effective concentration for traumatic oral ulcer healing.
\end{abstract}

Keywords: Epithelial thickness; fibroblast; salmon skin; traumatic ulcer

\section{INTRODUCTION}

The prevalence of traumatic oral ulcers in the world reaches $24 \%$ of the population (Silva et al., 2015). Traumatic oral ulcers are secondary lesions which resulted from the loss of epithelial lining of the mouth, and stimulate the free nerve ending in the lamina propria that causes pain (Laskaris, 2004; Regezi et al., 2015). Trauma can be 
from mechanical trauma, thermal trauma, iatrogenic trauma or chemicals (Neville et al., 2015).

The wound healing process requires an extracellular matrix which is the largest fibrous component consisting of collagen (Tracy et al., 2016). Collagen synthesis will begin immediately on the 3rd day after injury, which is after the proliferation of fibroblasts begins. Collagen synthesis will decrease slowly seven days after injury (Chattopadhyay \& Raines, 2014).

The development of microbial antibiotic resistance is the reason for the global search for antimicrobials from natural ingredients (Aslam et al., 2018). Natural materials that have low side effects or risk, are usually sourced from the sea (Bonifácio et al., 2014). Marine materials in Indonesia still have good prospects to encourage the economic recovery. Salmon is one of the marine sources which has potential as an export commodity. Processing of fisheries waste, such as salmon skin into collagen as treatment, however, is still limited (Silva et al., 2014).

Acetate acid extract from salmon has an ingredient that is rich in amino acids, proline and hydroxyproline which are the main components of collagen (Fan et al., 2017). External collagen plays a role in the maturation phase by helping natural collagen from within the body to give strength to new tissues and increase the organisation of collagen fibres during wound healing remodelling. The process of wound healing involves a variety of specialised cells, such as platelets, macrophages, fibroblasts, epithelial and endothelial cells. These cells interact with each other and with the extracellular matrix such as collagen. The collagen is synthesised and deposited primarily by fibroblasts. Fibroblast migration and deposition of extracellular matrix (ECM) components conferring increased the keratinocyte motility during re-epithelialisation (Krafts, 2010).
Based on the above background, the present study had tested the effectiveness of topical application of salmon skin acetic acid extracts in the healing process of traumatic oral ulcers in male Wistar rats, by analysing the epithelial thickness and the number of fibroblasts in the ulcer region, in search of an alternative material for the treatment of traumatic oral ulcers.

\section{MATERIALS AND METHODS}

This research is an experimental study using the post-test only control group design. The indicator used in analysing the therapeutic effect of salmon skin acetic acid extract on the healing process of traumatic oral ulcers is by analysing the thickness of the epithelium and the number of fibroblasts in the ulcer region. The sample criteria used were male Wistar rats, aged five months, body weight around $200 \mathrm{~g}$ to $250 \mathrm{~g}$. The study was conducted at the Laboratory of Biomedicine and Oral Biology, Faculty of Dentistry, Universitas Hang Tuah Surabaya. Approval for the experimental use of laboratory animals was obtained from the local Ethics Committee of the Faculty of Dentistry, Universitas Hang Tuah Surabaya, Indonesia (Ref. No.: 149/KEPK/XII/2018).

A total of 32 male Wistar rats were used in this research. The experimental groups were equally divided into four animal groups. The Wistar rats were provided by and kept under controlled environmental conditions $\left(24^{\circ} \mathrm{C}\right.$ relative humidity $40 \%$ to $60 \%, 12 \mathrm{~h}$ alternate light-dark cycles, food and water ad libitum) in the Animal Centre Laboratory, Faculty of Dentistry, Universitas Hang Tuah. After one week of acclimatisation, the rats were randomly allocated to four groups. Group 1 served as the control group and received no treatment, Group 2 was treated with salmon skin extract agent $4 \%(0.1 \mathrm{ml}$, $2 \times 1$ ), Group 3 was treated with salmon skin extract agent $5 \%(0.1 \mathrm{ml}, 2 \times 1)$, Group 4 was treated with salmon skin extract agent $6 \%(0.1 \mathrm{ml}, 2 \times 1)$ topically. 
After weighing was complete, each animal received a single intramuscular injection of $80 \mathrm{mg} / \mathrm{kg}$ of xylazine and $10 \mathrm{mg} / \mathrm{kg}$ of ketamine. Wounds were performed in all rats for the traumatic oral ulcer animal model. Punch biopsy of a $3 \mathrm{~mm}$ diameter is used as a tool to induce injury by removing the circular area of the lower labial mucosa. A tool equipped with a rubber stopper is placed on the punch to produce ulcers with a controlled depth of $5 \mathrm{~mm}$. Salmon skin extracts were prepared based on study by Bak et al. (2018). In the present study, salmon skin extracts with concentrations of $4 \%, 5 \%$ and $6 \%$ were used. The application of salmon skin extracts were made twice a day with a cotton swab for seven days and the lesions were treated daily. The animals were sacrificed at the end of the 7 th day study period. A section of the lower labial mucosa containing the induced ulcer was collected, fixed with $10 \%$ paraformaldehyde, embedded in paraffin and routinely processed for hematoxylin-eosin staining to count the number of fibroblasts in each group using graticule and seen under a microscope with $400 \times$ magnification. The specimens were analysed by two blinded, calibrated pathologists who evaluated the epithelial thickness and the number of fibroblasts. Data are presented as mean \pm SD. Statistically significant differences between groups were determined by oneway ANOVA followed by least significant differences (LSD) test at $p<0.05$ using SPSS 23.0 for Windows (IBM, Armonk, NY).

\section{RESULTS}

The results obtained were presented in Table 1 and Fig. 1. There was a statistically significant difference between all groups. Statistically significant $(p<0.001)$ increase in epithelial thickness and the number of fibroblasts were observed in salmon skin topically treated groups as compared to the control group. Traumatic oral ulcer group with no treatment had the lowest epithelial thickness and the number of fibroblasts amongst the study groups. There were significant differences in epithelial thickness and the number of fibroblasts between the groups treated using salmon skin extracts with concentrations of $4 \%, 5 \%$, and $6 \%$. The higher the therapeutic concentration, the higher the thickness of the epithelium and the number of fibroblasts. Salmon skin extract $6 \%$ topically treated group had the highest epithelial thickness and the number of fibroblasts amongst the study groups.

\section{DISCUSSION}

Wistar rats are used because they provide several advantages compared to other animals, including low cost, easy manipulation, low maintenance in the environment, controlled sanitation and special diets (Cavalcante et al., 2011). Wistar rats and human oral mucosa have similarities, which consist of complete epithelial tissues on the surface and connective tissues, called basal lamina

Table 1. Means and SD of epithelial thickness and the number of fibroblasts from each group

\begin{tabular}{|c|c|c|c|c|c|c|c|}
\hline \multirow[t]{2}{*}{ Group } & \multirow[t]{2}{*}{$\mathbf{N}$} & \multicolumn{2}{|c|}{ Epithelial thickness } & \multirow[t]{2}{*}{$\boldsymbol{p}$} & \multicolumn{2}{|c|}{$\begin{array}{l}\text { The number of } \\
\text { fibroblasts }\end{array}$} & \multirow[t]{2}{*}{$p$} \\
\hline & & Mean & SD & & Mean & SD & \\
\hline Control & 8 & 6.70 & 2.55 & & 22.22 & 3.83 & \\
\hline Salmon skin extract with concentrations of $4 \%$ & 8 & 148.30 & 23.24 & * & 272.89 & 55.57 & * \\
\hline Salmon skin extract with concentrations of $5 \%$ & 8 & 159.85 & 30.18 & * & 276.00 & 66.82 & * \\
\hline Salmon skin extract with concentrations of $6 \%$ & 8 & 162.96 & 33.97 & * & 314.52 & 88.82 & * \\
\hline
\end{tabular}

Note: ${ }^{*} p<0.05$, significantly different from the control group. 
(a)

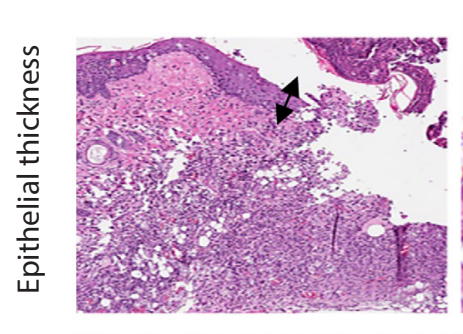

(b)

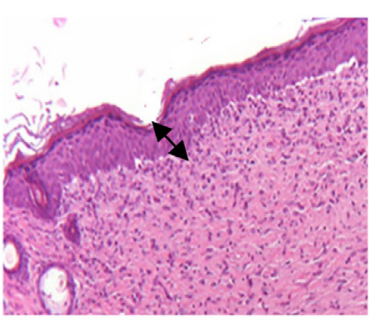

(c)
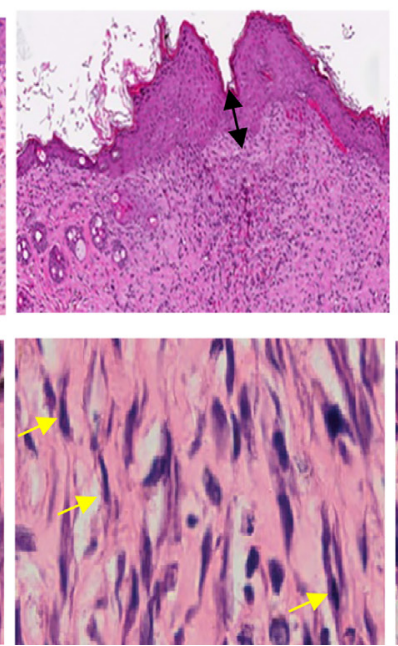

(d)
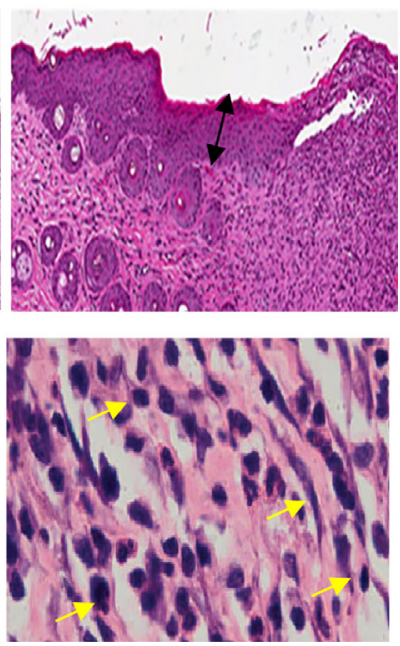

Fig. 1 Histological features of epithelial thickness and the number of fibroblasts in traumatic oral ulcer healing. (a) Group 1 served as the control group and received no treatment; (b) Group 2 was treated with salmon skin extract agent 4\%; (c) Group 3 was treated with salmon skin extract agent 5\%; (d) Group 4 was treated with salmon skin extract agent $6 \%$.

which provides support and nutrition to the epithelium (Sullivan et al., 2001).

The result of the present study proves that collagen peptides derived from the salmon skin extracts can accelerate the wound healing process, thus could be a potential therapeutic product that may be beneficial in wound clinics. Overall treatment with collagen peptide from salmon skin extracts on rats with full-thickness excised wounds had positive result in wound contraction as compared with the control. Histological assessment of collagen peptides treated rats models showed a remarkable signs of re-epithelialisation, tissue regeneration and increased fibroblast proliferation. Reepithelialisation during the ulcer recovery process can be examined by measuring the thickness of the epithelial layer on two opposite sides of the ulcer. Reepithelialisation is a complex series in the process of wound healing, through various stages of repair, proliferation and differentiation of keratinocytes (Pastar et al., 2014; Politis et al., 2016). The proliferation of fibroblasts determines the outcome of wound healing. Fibroblasts will produce collagen which will link the wound, and fibroblasts will also affect the process of reepithelialisation that will close the wound (Takeuchi et al., 2017).

Peptide bioactivity from fish waste can be used as medicine because it has antihypertensive, antioxidative, antimicrobial, neuroprotective, antihyperglycemic and anti-aging properties (Venkatesan et al., 2017; Cheung et al., 2015). Marine-derived collagen has also been widely used for tissue engineering because of its excellent bioactive properties such as biocompatibility, low antigenicity, high biodegradability and cell growth potential (Cho et al., 2014; Subhan et al., 2015).

\section{CONCLUSION}

The results showed that the thickness of the epithelium and the number of fibroblasts increased with the increasing concentrations of salmon skin extracts. The higher the concentration of salmon skin extracts, the higher the content of collagen, to accelerate the process of re-epithelialisation and proliferation of fibroblast cells in the healing process of traumatic oral ulcers. 


\section{ACKNOWLEDGEMENTS}

We thank Universitas Hang Tuah for the internal grant (Ref. No. 030/PTS.188.H13/ $\mathrm{B} / \mathrm{X} / 2018$ ). We would also like to thank the students of the Faculty of Dentistry, Universitas Hang Tuah who participated in the fieldwork.

\section{REFERENCES}

Aslam B, Wang W, Arshad MI, Khurshid M, Muzammil S, Rasool MH et al. (2018). Antibiotic resistance: A rundown of a global crisis. Infect Drug Resist, 11: 1645-1658. https://doi.org/10.2147/IDR .S173867

Bak SY, Lee SW, Choi CH, Kim HW (2018). Assessment of the influence of acetic acid residue on Type I collagen during isolation and characterization. Materials (Basel), 11(12): 2518. https://doi.org/10.3390/ma 11122518

Bonifácio BV, dos Santos Ramos MA, da Silva PB, Bauab TM (2014). Antimicrobial activity of natural products against Helicobacter pylori: A review. Ann Clin Microbiol Antimicrob, 13: 54. https://doi.org/ 10.1186/s12941-014-0054-0

Cavalcante GM, Sousa de Paula RJ, Souza LP, Sousa FB, Mota MR, Alves AP (2011). Experimental model of traumatic ulcer in the cheek mucosa of rats. Acta Cir Bras, 26(3): 227-234. https://doi.org/10.1590/ s0102-86502011000300012

Chattopadhyay S, Raines RT (2014). Review collagen-based biomaterials for wound healing. Biopolymers, 101(8): 821-833. https://doi.org/10.1002/bip.22486

Cheung RC, Ng TB, Wong JH (2015). Marine peptides: Bioactivities and applications. Mar Drugs, 13(7): 4006-4043. https://doi .org/10.3390/md13074006

Cho JK, Jin YG, Rha SJ, Kim SJ, Hwang JH (2014). Biochemical characteristics of four marine fish skins in Korea. Food Chem, 159: 200-207. https://doi.org/10.1016/j. foodchem.2014.03.012
Fan H, Dumont MJ, Simpson BK (2017). Extraction of gelatin from salmon (Salmo salar) fish skin using trypsin-aided process: Optimization by Plackett-Burman and response surface methodological approaches. F Food Sci Technol, 54(12): 4000-4008. https://doi.org/10.1007/s13197 $-017-2864-5$

Krafts KP (2010). Tissue repair: The hidden drama. Organogenesis, 6(4): 225-233. https://doi.org/10.4161/org.6.4.12555

Laskaris G (2004). Treatment of Oral Diseases: $A$ Concise Textbook. New York: Thieme, pp. 169.

Neville B, Damm DD, Allen C, Chi A (2015). Oral and Maxillofacial Pathology, 4th edn. Philadelphia: W.B. Saunders, pp. 260-262.

Pastar I, Stojadinovic O, Yin NC, Ramirez H, Nusbaum AG, Sawaya A et al. (2014). Epithelialization in wound healing: A comprehensive review. Adv Wound Care (New Rochelle), 3(7): 445-464. https://doi .org/10.1089/wound.2013.0473

Politis C, Schoenaers J, Jacobs R, Agbaje JO (2016). Wound healing problems in the mouth. Front Physiol, 7: 507. https://doi .org/10.3389/fphys.2016.00507

Regezi JA, Sciubba JJ, Jordan RCK (2015). Oral Pathology: Clinical Pathologic Correlations, 7th edn. Philadelphia: W.B. Saunders, pp. 23-26.

Silva MF, Barbosa KG, Pereira JV, Bento PM, Godoy GP, Gomes DQ (2015). Prevalence of oral mucosal lesions among patients with diabetes mellitus types 1 and 2. An Bras Dermatol, 90(1): 49-53. https://doi.org/10 $.1590 / \mathrm{abd} 1806-4841.20153089$

Silva TH, Moreira-Silva J, Marques AL, Domingues A, Bayon Y, Reis RL (2014). Marine origin collagens and its potential applications. Mar Drugs, 12(12): 58815901. https://doi.org/10.3390/md12125881

Subhan F, Ikram M, Shehzad A, Ghafoor A (2015). Marine collagen: An emerging player in biomedical applications. $\mathcal{f}$ Food Sci Technol, 52(8): 4703-4707. https://doi .org/10.1007/s13197-014-1652-8 
Sullivan TP, Eaglstein WH, Davis SC, Mertz P (2001). The pig as a model for human wound healing. Wound Rep Reg, 9(2): 66-76. https://doi.org/10.1046/j.1524-475x $.2001 .00066 . x$

Takeuchi Y, Ueno K, Mizoguchi T, Samura M, Harada T, Oga A et al. (2017). Ulcer healing effect of autologous mixed sheets consisting of fibroblasts and peripheral blood mononuclear cells in rabbit ischemic hind limb. Am 7 Transl Res, 9(5): 23402351 .
Tracy LE, Minasian RA, Caterson EJ (2016). Extracellular matrix and dermal fibroblast function in the healing wound. Adv Wound Care (New Rochelle), 5(3): 119-136. https://doi.org/10.1089/wound.2014.0561

Venkatesan J, Anil S, Kim SK, Shim MS (2017). Marine fish proteins and peptides for cosmeceuticals: A review. Mar Drugs, 15(5): 143. https://doi.org/10.3390/md150 50143 